\title{
Crude extract from a hardcoral-associated bacterium Virgibacillus salarius PHC-44-04 inhibiting growth of Multidrug-Resistant Enterobacter aerogenes human pathogen
}

\author{
DIAH AYUNINGRUM ${ }^{1, \vartheta}$, SAKTI IMAM MUCHLISSIN ${ }^{2,3}$, AGUS TRIANTO ${ }^{2,3}$, OCKY KARNA RADJASA $^{2,3}$, \\ AGUS SABDONO ${ }^{2,3}$ \\ ${ }^{1}$ Program of Coastal Resources Management, Faculty of Fisheries and Marine Sciences, Universitas Diponegoro. Jl. Prof. Soedharto, S.H. Tembalang, \\ Semarang 50275. Central Java, Indonesia. Tel.: +62-24-7474698, `email: diah.ayuningrum@ student.undip.ac.id \\ ${ }^{2}$ Tropical Marine Biotechnology Laboratory, Faculty of Fisheries and Marine Sciences, Universitas Diponegoro. Jl. Prof. Soedharto, S.H. Tembalang, \\ Semarang 50275. Central Java, Indonesia \\ ${ }^{3}$ Departement of Marine Science, Faculty of Fisheries and Marine Sciences, Universitas Diponegoro. Jl. Prof. Soedharto, S.H. Tembalang, Semarang \\ 50275. Central Java, Indonesia
}

Manuscript received: 20 June 2020. Revision accepted: 21 August 2020.

\begin{abstract}
Ayuningrum D, Muchlissin SI, Trianto A, Radjasa OK, Sabdono A. 2020. Crude extract from a hardcoral-associated bacterium Virgibacillus salarius PHC-44-04 inhibiting growth of Multidrug-Resistant Enterobacter aerogenes human pathogen. Biofarmasi J Nat Prod Biochem 18: 82-87. Hardcoral-associated bacteria are potential sources of natural product compounds with a wide range of activities, i.e., antibacterial activity, antiviral, anticancer, antifungal, etc. Virgibacillus salarius PHC-44-04 is a gram-positive bacterium isolated in prior research from hard coral Pavona sp. collected from Panjang Island, Jepara, Indonesia. This bacterium at the screening phase was showing high antibacterial activity against Multidrug-Resistant Enterobacter aerogenes (MDR-EA). Therefore, this paper has aim to deliver the result of the crude extract antibacterial test from $V$. salarius PHC-44-04 after being cultivated in a liquid medium, to know the efficiency of using supernatant and pellet extract, and to determine in which concentration was the minimum for antibacterial activity. The cultivation of bacterial isolates was using liquid medium Nutrient Broth, and the production of crude extract was using the liquid-liquid extraction method. The liquid medium containing bacterial cells were separated using a centrifuge at 8,000 rpm and became supernatant and pellet. The supernatant was extracted using ethyl acetate, while the pellet was extracted using methanol. The antibacterial test from both crude extract from supernatant and pellet was using disk diffusion method with several concentration as follows: $15 \mu \mathrm{g} / \mathrm{mL}, 30 \mu \mathrm{g} / \mathrm{mL}, 60 \mu \mathrm{g} / \mathrm{mL}, 90 \mu \mathrm{g} / \mathrm{mL}, 180 \mu \mathrm{g} / \mathrm{mL}, 250 \mu \mathrm{g} / \mathrm{mL}, 350 \mu \mathrm{g} / \mathrm{mL}$, and $500 \mu \mathrm{g} / \mathrm{mL}$. Each concentration was repeated in three replicates. The crude extract produced from $700 \mathrm{~mL}$ supernatant was $0.0667 \mathrm{~g}$ and from $50 \mathrm{~mL}$ pellets was 0.0320 . The pellet crude extract has a higher mass but does not have antibacterial activity against MDR-EA. The result showed an only supernatant crude extract of $V$. salarius showed antibacterial activity against the MDR-EA bacterium. The minimal crude extract concentration to inhibit the growth of MDR-EA was $60 \mu \mathrm{g} / \mathrm{mL}$. Meanwhile, the best concentration for exhibiting antibacterial activity was $500 \mu \mathrm{g} / \mathrm{mL}$ with a zone of inhibition (ZOI) diameter of $11.77 \pm 0.8730 \mathrm{~mm}$. Thus, supernatant should be the main source of crude extract production rather than the pellet to get high antibacterial activity.
\end{abstract}

Keywords: Antibacterial activity, crude extract, MDR-Enterobacter aerogenes, Pavona, Virgibacillus salarius

\section{INTRODUCTION}

Infectious diseases could be transferred from one person to another directly or indirectly by vectors. The causes of infectious disease mostly are pathogens which belong to bacteria, viruses, fungi, and parasites. Those bacteria, because infectious diseases have evolved, have become multidrug-resistant bacteria. This resistance responds to natural selection, mutation, gene transfer, irrational use of antibiotics, etc. (National Institute of Allergy and Infectious Diseases (NIAID) 2011). According to Suwantarat and Carroll (2016), gram-negative bacteria are easier to evolve, becoming Multidrug-Resistant Gramnegative bacteria (MDRGN) with the highest contribution of various cases associated with admission to medical wards, respiratory tract origin, and hospital-onset of infection in Southeast Asia. Multidrug-Resistant Enterobacter aerogenes (MDR-EA) is the main source of nosocomial infection, as many as 53\% (Cornejo-Juarez et al. 2015), with some diseases such as bacteremia, urinary tract infection, and wound infection (Khan et al. 2015). This kind of Multidrug-Resistant (MDR) bacteria is already resistant to some antibiotics, e.g., imipenem (89.7\%), cefoxitin (50.3-74.2\%), ciprofloxacin (51.4\%) and levofloxacin (54.4\%) (Biendo et al. 2008; and Lu et al. 2012). Thus, the search for a new antibiotic candidate is urgently needed.

The exploration of natural products for drug or antibiotic discovery was begun long ago, not starting in 1908 when the first antibiotic was discovered (Silver 2011). Since then, many sources have been explored to find some interesting compounds that have antibacterial activity, not only from land but also from the marine environment, which is considered more unique and has a lot of potential compounds. The source of natural products from marine organisms comes mostly from the invertebrates, i.e., sponges, corals (hard corals and soft 
corals), tunicates, nudibranchs, and many more (Ayuningrum et al., 2019; Kristiana et al., 2019). Corals are a source of potential compounds that have a lot of activities as antibacterial, antiviral, anti-inflammatory, cytotoxic, etc. But the direct exploration of the coral organisms and invertebrate needs tons of individuals to yield low amounts of active compounds, which later negatively impact the environment. Thus, many researchers prospect the potential from the symbiont or associated microorganisms.

Bacterial-symbiont in marine invertebrates, especially corals, has become the main source for exploring antibacterial compounds for drug discovery. This culturedependent method began with isolating bacterial symbionts, screening, liquid cultivation, and extraction and purification of antibacterial compounds. Liquid cultivation and extraction play an important role in the next processes because most bacteria cannot retain the compound after being cultivated from solid to liquid medium. According to prior research, we have successfully isolated a bacterium from a hard coral Pavona sp. According to morphological and molecular characterization, the bacterium was identified as Virgibacillus salarius PHC-44-04. The screening process showed that this bacterium has strong activity against MDR-EA. This research aims to know the crude extract antibacterial activity of $V$. salarius PHC-44-4 after cultivation in a liquid medium, know which part of the bacterial culture has antibacterial activity, and estimate the best concentration to inhibit the growth of MDR-EA. That information is important to prepare the scaling-up process of the bacterial culture in order to purify the antibacterial compounds without losing the antibacterial activity from solid to liquid medium.

\section{MATERIALS AND METHODS}

\section{Chemical and reagents}

Nutrient Broth (Hi-media), Nutrient Agar (Hi-media), Muller Hilton Broth (Hi-media), Muller Hilton Agar (Himedia), Aquabides (Onemed), Ethyl Acetate (Merck), Methanol (Merck), Dimethyl Sulfoxide (Merck), Paperdisc blank (Advantec, Japan), Paperdisc with Antibiotic for Positive control used chloramphenicol $30 \mu \mathrm{g} / \mathrm{disc}$ (Oxoid), Nitrogen Gas (PT. Samator, Semarang, Indonesia).

\section{Hard coral specimen identification}

Hard Coral sampling was conducted in January 2016 at Panjang Island, Jepara, Indonesia. Hard corals were collected using SCUBA gears (SCUBAPRO) at a depth of 3-6 m. Hard corals were placed separately into plastic ziplock to avoid contact with the environment. Hard corals were identified using Veron's (2000) instructions by observing the shape and structure of corallite using a stereomicroscope. Then, the corallite structure was matched with the guidebook. After that, the specimen was stored in alcohol $96 \%$ for long-term preservation.

\section{Bacterial strains and pathogen preparation}

Virgibacillus salarius PHC-44-04 was isolated from hard coral Pavona sp. from previous research by
Ayuningrum et al. (2017). MDR E. aerogenes (MDR-EA) pathogen was obtained from Dr. Karyadi Hospital, Semarang. MDR-EA was cultured a day before antibacterial assay in a solid medium (Muller Hilton Agar). Then, pick 3-4 colonies of MDR and placed in into the sterile physiologic salt solution and measure until they reach $0.5 \mathrm{Mc}$ Farland or density of $1 \times 10^{8} \mathrm{CFU} / \mathrm{mL}$ (Bacteria solution were compared using standard McFarland from Hi-media.

\section{Production of crude extract}

The production of crude extract was started by cultivating in liquid culture of $500 \mathrm{~mL}$ marine NB. The cultures were shaken at $110 \mathrm{rpm}$ for 3 days at room temperature $\left(29 \pm 2{ }^{\circ} \mathrm{C}\right)$. The harvest was done by centrifugation to separate the cell from the medium at $6,000 \mathrm{rpm}$ for 10 minutes. The medium was mixed with ethyl acetate (EtOAc) and the cell with methanol $(\mathrm{MeOH})$ in a $1: 1(\mathrm{v} / \mathrm{v})$ ratio. Both suspensions were homogenized by shaking for 15 minutes. Then, the organic layer from the water was separated using a separatory funnel (Pyrex). The organic layer was evaporated using a rotary evaporator (Buchi R-124) at $40^{\circ} \mathrm{C}$. Further, the mixture of pellets with $\mathrm{MeOH}$ was separated using filter paper. The extraction was collected into the clean vial bottle and concentrated using nitrogen gas.

\section{Antibacterial test of crude extract}

The antibacterial test against MDR-EA was conducted using the disk diffusion method (Yoghiapiscessa et al., 2016). Some concentrations used in this test were consisting of $15 \mu \mathrm{g} / \mathrm{mL}, 30 \mu \mathrm{g} / \mathrm{mL}, 60 \mu \mathrm{g} / \mathrm{mL}, 90 \mu \mathrm{g} / \mathrm{mL}$, $180 \mu \mathrm{g} / \mathrm{mL}, 250 \mu \mathrm{g} / \mathrm{mL}, 350 \mu \mathrm{g} / \mathrm{mL}$, dan $500 \mu \mathrm{g} / \mathrm{mL}$ with three replications of each concentration. The MDR-EA bacterium was refreshed a day before, then measured to be 0,5 McFarland, and after that, being swapped onto Muller Hinton Agar (MHA) medium. As many as $30 \mu \mathrm{l}$ extracts of each concentration were dropped onto each paper disc and placed on the MHA medium containing swapped MDR-EA bacterium. This experiment used Chloramphenicol 30 $\mu \mathrm{g} / \mathrm{disc}$ as the positive control and EtOAc or $\mathrm{MeOH}$ as the negative control, depending on which solvent was extracted. The plates were incubated at $37^{\circ} \mathrm{C}$ overnight and observed in the clear zone. All experiment measurement data were performed with Vernier Caliper from Tricle Brand in three replicates and expressed as mean \pm SD $(\mathrm{n}=3)$.

\section{RESULTS AND DISCUSSION}

\section{Identification of hard coral}

Hard coral specimens from Panjang Island, Jepara, have been identified as Pavona sp. (Figure 1). Colonies in the form of short sheets, thick and upright. Corallites were present on both surfaces, irregular, small without walls, and interconnected septocostals. Under watercolor was light brown or grayish.

According to the coral identification book The IndoPacific Coral Finder (Kelley 2009) and the website Corals 
of the Worlds (coral.aims.gov.au), the coral specimen was identified as Pavona sp. The characterization of Pavona sp. was already described in Suharsono (2008) showed that the body of coral has greenish-brown color and shape of the plate. The zooxanthellae microsymbiont was responsible for the color. The growth of coral colonies was massive and encrusting. Corallite does not have a clear wall; present on both surfaces, irregular, small, and without a wall. Septocostae within the close corallite is united and developed well to become a dominant appearance.

This genus of coral is found in Panjang Island waters, in the dept of 0.5 up to 7 meters. The other coral families grow in these waters, according to Munasik et al. (2012), including 25 genera, which belong to 11 different families. Those families consist of Acroporidae, Agariciidae, Dendrophyllidae, Faviidae, Fungiidae, Merulinidae, Muscidae, Oculinidae, Ectinidae, Pociloporidae, and Poritidae. The genus Pavona identified in this research belongs to the family Agaricidae. The classification of Pavona sp. (Hoeksema 2015) is as follows, Kingdom: Animalia, Phylum: Cnidaria, Class: Anthozoa, Subclass: Hexacorallia, Order: Scleractinia, Family: Agariciidae, Genus: Pavona, and Species: Pavona sp.
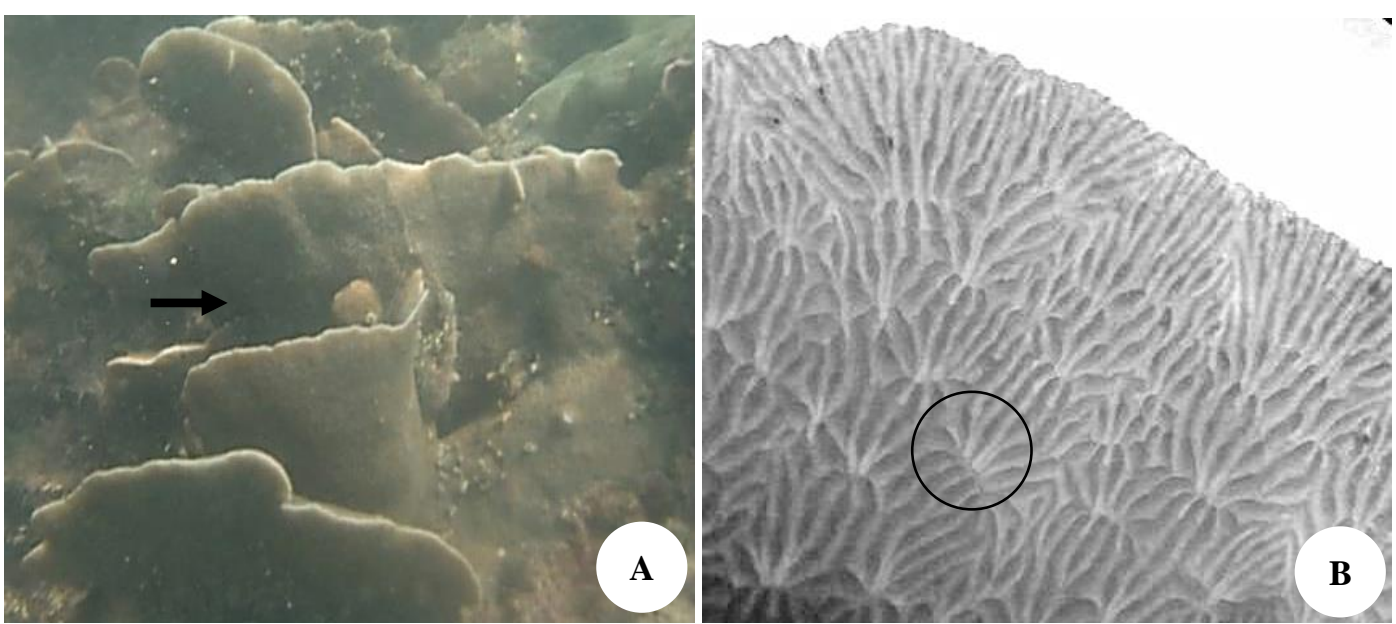

Figure 1. A. The underwater photography or hard coral Pavona sp., the colony of hard coral (black arrow), B. Corralite (black circle) observation using a stereo microscope

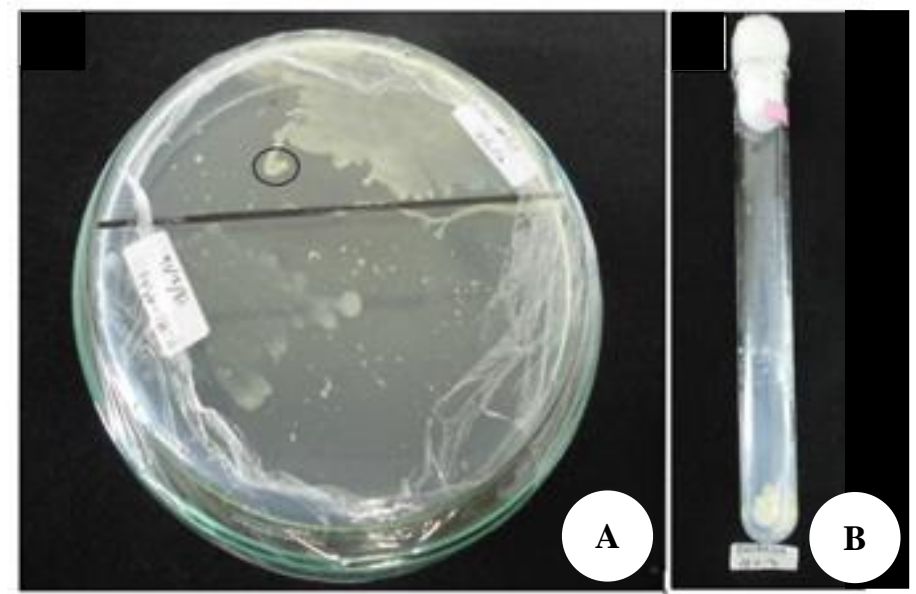

Figure 2. A. The morphology of Virgibacillus salarius PHC-44-04 colony (black circle), B. The preservation of the strain in agar slant 


\section{Production of crude extract}

The supernatant crude extract had a mass of $0,0667 \mathrm{~g}$, and the pellet crude extract had a mass of $0.0320 \mathrm{~g}$ (Table 1). The results showed that the pellet contains more polar compounds, which is different from the supernatant, which contains fewer polar compounds. Nevertheless, both extracts had the same paste forms and greenish-yellow colors.

The extraction method influences the compounds inside the crude extract. The use of different solvents has the purpose of determining the solvent's effectiveness in extracting the compounds inside the supernatant and pellet. Ethyl acetate solvent (polarity index 4.4) is used to extract semi-polar and volatile compounds because this solvent can dissolve semi-polar compounds, i.e., flavonoid aglycone, non-toxic, and hygroscopic (Harborne, 1987). Moreover, ethyl acetate is able to dissolve compounds that have antibacterial activity, such as flavonoids and polyhydroxy phenolics (Wardhani and Sulistyani 2012). Meanwhile, the use of methanol to extract the compounds in the pellets is because methanol (polarity index 5.1) can bind all the chemical components that are more polar than ethyl acetate. The volume of supernatant to solvent has a ratio of 1: 1; this reason was to minimize the saturation level of solvent in binding to the bioactive compounds inside the supernatant (Yoghiapiscessa et al. 2016). The temperature remained low during the evaporation process to keep the active compounds in the crude extract.

\section{Antibacterial assay}

After being extracted, a total of 8 concentrations of crude extracts, both supernatant, and pellet, were tested against MDR-EA. All concentrations of supernatant crude extracts demonstrated inhibitory activities against MDR-
$\mathrm{AB}$; in contrast, the pellet crude extracts showed no activity (Table 2, Figure 3). The lowest activity is at a concentration of $15 \mu \mathrm{g} / \mathrm{mL}$ with a mean inhibition zone of $9.57 \mathrm{~mm}$. The largest inhibition zone was $11.77 \mathrm{~mm}$ in the highest $500 \mu \mathrm{g} / \mathrm{mL}$ concentration, which means the higher the crude extract concentration, the bigger the inhibition zone. The inhibition zones of crude extracts against MDR$\mathrm{AB}$ are shown in Figure 3.

The antibacterial activity test in this research uses Muller Hinton Agar (MHA) as the medium because it is recommended by the Food and Drug Association (FDA) and the World Health Organization (WHO) to test the antibacterial activity mainly for aerobic bacteria and facultative anaerobic bacteria. This medium contains a low sulfonamide concentration, trimethoprim, and tetracycline inhibitors and provides optimal pathogen growth. Furthermore, giving the negative control (solvent) in the antibacterial test function to determine if the negative control shows a positive result, the extract is toxic to the bacteria. To choose the positive control should be concerned about the sensitivity of the antibiotic against MDR-AB which in this research, we use chloramphenicol $30 \mu \mathrm{g} /$ disc. The largest inhibition zone was $11.77 \mathrm{~mm}$ in the highest $500 \mu \mathrm{g} / \mathrm{mL}$ concentration. This different result found in pellets extract showed no activity at all. It showed that only the supernatant extract has activity against MDRAB. This means that the active compounds in bacterial secondary metabolites are secreted from the cell. This is confirmed by Kristiana et al. (2020); compounds secreted by bacteria must cause the antibacterial activity of supernatant. So, when centrifuged, it is separated between the active compounds remaining in the pellet and primary metabolites such as protein in the cells (pellets).

Table 1. The production of crude extract Virgibacillus salarius PHC-44-04

\begin{tabular}{lcccc}
\hline & Culture volume $(\mathbf{m L})$ & $\begin{array}{c}\text { Solvent volume } \\
(\mathbf{m L})\end{array}$ & $\begin{array}{c}\text { Mass of crude } \\
\text { extract }(\mathbf{g})\end{array}$ & Form \\
\hline Supernatant & 700 & 700 & 0.0667 & Paste \\
Pellet & 50 & 50 & 0.0320 & Greenish-yellow \\
\hline
\end{tabular}

Table 2. The inhibition zone of crude extract Virgibacillus salarius strain PHC-44-04 against MDR-EA

\begin{tabular}{|c|c|c|c|}
\hline \multirow{2}{*}{\multicolumn{2}{|c|}{ Concentration $(\mu \mathrm{g} / \mathrm{mL})$}} & \multicolumn{2}{|c|}{ Diameter of Inhibition zone (mm) } \\
\hline & & \multirow{2}{*}{$\begin{array}{l}\text { Supernatant } \\
9.57 \pm 0.4497\end{array}$} & \multirow{2}{*}{$\begin{array}{l}\text { Pellet } \\
8 \pm 0.0000\end{array}$} \\
\hline & 15 & & \\
\hline & 30 & $9.60 \pm 0.2944$ & $8 \pm 0.0000$ \\
\hline & 60 & $10.12 \pm 0.6575$ & $8 \pm 0.0000$ \\
\hline & 90 & $10.53 \pm 0.8576$ & $8 \pm 0.0000$ \\
\hline & 150 & $10.63 \pm 0.4497$ & $8 \pm 0.0000$ \\
\hline & 250 & $10.70 \pm 0.2160$ & $8 \pm 0.0000$ \\
\hline & 350 & $10.84 \pm 0.6556$ & $8 \pm 0.0000$ \\
\hline & 500 & $11.77 \pm 0.8730$ & $8 \pm 0.0000$ \\
\hline Control (+) & Chloramphenicol & $21.63 \pm 0.6650$ & $21.85 \pm 0.8879$ \\
\hline \multirow[t]{2}{*}{ Control (-) } & Ethyl acetate & $8.00 \pm 0.0000$ & - \\
\hline & Methanol & - & $8.00 \pm 0.0000$ \\
\hline
\end{tabular}

Note: the disc diameter was $8 \mathrm{~mm}$ 


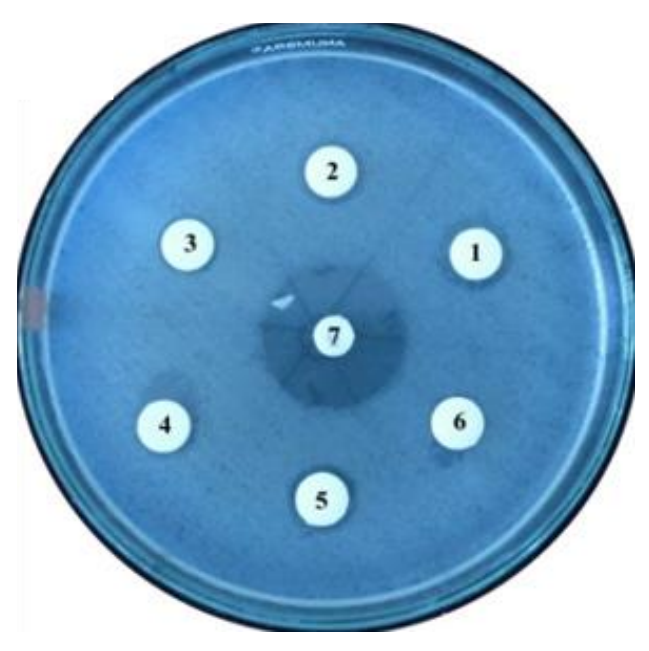

A

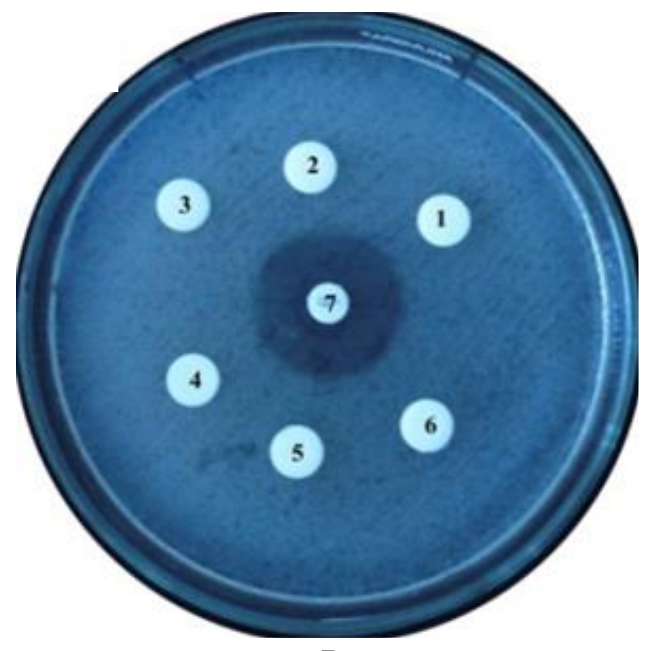

B

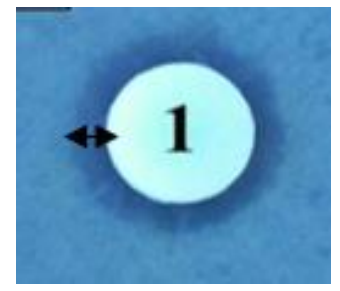

$\mathbf{C}$

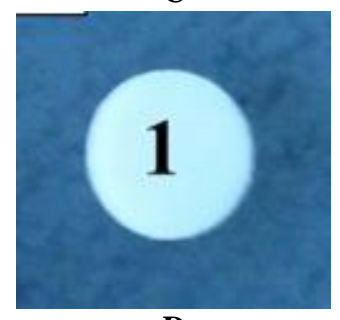

D

Figure 3. The antibacterial activity of supernatant (A) and pelet (B) showing inhibition zones against MDR-EA. (C) Close-up of disc containing supernatant extracts with concentration of $15 \mu \mathrm{g} / \mathrm{mL}$ inhibition zone of $9,57 \mathrm{~mm}$. (D) Close-up of disc containing no inhibition zone. Number 1: $15 \mu \mathrm{g} / \mathrm{mL}, 2: 30 \mu \mathrm{g} / \mathrm{mL}, 3: 60 \mu \mathrm{g} / \mathrm{mL}, 4: 90 \mu \mathrm{g} / \mathrm{mL}, 5: 150 \mu \mathrm{g} / \mathrm{mL}, 6: 250 \mu \mathrm{g} / \mathrm{mL}$. 7: Positive control (antibiotics)

The test results indicate that the concentration of each extract gives different sizes in the zone of inhibition. The higher concentration of crude extract, the greater zone of inhibition formed. This finding also supports the previous reports by Gonemali et al. (2018) and Bhalodia and Shukla (2011). Besides, the type of tested bacteria also influences the diameter of the inhibition zone. This is related to bacteria's enzymes or other substances, giving different effects to the active substance contained in isolate PHC44/04. This enzyme can be toxic to antibacterial agents, thereby inactivating the active substance by destroying or damaging the active substance (Ramadhan et al., 2015). MDR E. aerogenes is a bacterium with complex resistance mechanisms such as the enzyme beta-lactamase, which can damage the active side of antibiotics, and have an efflux pump (Dzidic et al. 2008 and Nikaido 2009. This is what causes the small zone of inhibition to form. The other factors that affect the diameter of the inhibition zone are the disc's ability to absorb extract, $\mathrm{pH}$ of the medium, the reaction between active ingredients with medium, incubation temperature, etc.

In conclusion, to retain the antibacterial activity from solid medium to liquid, bacterial isolate should be cultivated in seed culture before moving to big-scale culture. The only supernatant crude extract shows antibacterial activity therefore to get antibacterial compounds, liquid-liquid extraction should be conducted from the cultivation medium, not the bacterial cell. Supernatant crude extract of $V$. salarius has maximum activity against MDR-EA activity with a minimal concentration of $60 \mu \mathrm{g} / \mathrm{mL}$.

\section{ACKNOWLEDGEMENTS}

Authors thank Diah P. Wijayanti, Handung Nuryadi, Meezan A. Asagabaldan, Rhesi Kristiana, Prasetyo Abi W, and Dio Dirgantara for the help during pre-sampling and sampling. This research was partially funded by a Research Grant from the Indonesian Ministry of Research and Higher Education in the scheme of PMDSU.

\section{REFERENCES}

Ayuningrum D, Kristiana R, Asagabaldan MA, Sabdono A, Radjasa OK, Nuryadi H, Trianto A. 2017. Isolation, characterisation and antagonistic activity of bacteria symbionts hard coral Pavona sp. isolated from Panjang Island, Jepara against infectious Multi-drug Resistant (MDR) bacteria. IOP Conf Ser Earth Environ Sci 55: 012029 DOI: 10.1088/1755-1315/55/1/012029.

Ayuningrum D, Liu Y, Riyanti, Sibero MT, Kristiana R, Asagabaldan MA, Wuisan, ZG, Trianto A, Radjasa OK, Sabdono A, Schaeberle TF. 2019. Tunicate-associated bacteria show great potential for the discovery of antimicrobial compounds. PLoS ONE 14 (3): e0213797. DOI: $10.1371 /$ journal.pone.0213797.

Bhalodia, N. R., and Shukla, V. J. 2011. Antibacterial and antifungal activities from leaf extracts of Cassia fistula 1.: an ethnomedicinal plant. J Adv Pharm Technol Res 2: 104-109. DOI: 10.4103/22314040.82956.

Biendo M, Canarelli B, Thomas D, Rousseau F, Hamdad F, Adjide C, Lauras G, Eb F. 2008. Successive emergence of extended-spectrum $\beta$ lactamase-producing and carbapenemase-producing Enterobacter aerogenes isolates in a university hospital. J Clin. Microbiol 46 (3): 1037-1044

Cornejo-Juarez P, Compte DV, Perez-Jimenez C, Namendys-Silva SA, Sandoval-Hernandez S, Volkow-Fernandez P. 2015. The impact of hospital-acquired infections with multidrug-resistant bacteria in an oncology intensive care unit. Intl J Infect Dis 31: 31-34.

Dzidic, S., Suskovic, J., and Kos, B. 2008. Antibiotic resistance mechanisms in bacteria: biochemical and genetic aspects. Food Technol. Biotechnol. 46 (1): 11-21.

Gonelimali FD, Lin J, Miao W, Xuan J, Charles F, Chen M, Hatab SR. 2018. Antimicrobial properties and mechanism of action of some plant extract against food pathogens and spoilage microorganisms. Front Microbiol 9: 1639. DOI: 10.3389/fmicb.2018.01639.

Harborne JB. 1987. Metode Fitokimia, diterjemahkan oleh Kosasih Padmawinata dan Iwang Soediro, Penerbit ITB, Bandung. [Indonesian]

Hoeksema B. 2015. Pavona decussata (Dana, 1846). Accessed through: World Register of Marine Species 
http://www.marinespecies.org/aphia.php?p=taxdetails\&id=207320 on 2016-08-02

Kelley R. 2009. The Indo Pacific Coral Finder. Russel Kelley Publishing, Australia.

Khan HA, Ahmad A. Mehboob R. 2015. Nosocomial infections and their control strategies. Asian Pac J Trop Biomed 5 (7): 509-514.

Kristiana R, Bedoux G, Pals G, Mudianta, Taupin L, Marty C, Asagabaldan MA, Ayuningum D, Trianto A, Bourgougnon N, Radjasa OK, Sabdono A. 2020. Bioactivity of compounds secreted by symbiont bacteria of Nudibranchs from Indonesia. PeerJ 8: e8093. https://peerj.com/articles/8093/

Kuang W, Li J, Zhang S, Long L. 2015. Diversity and distribution of bacteria associated with reef coral Porites lutea. Front Microbiol 6: 1094. DOI: $10.3389 /$ fmicb.2015.01094

Lu P, Liu Y, Toh H, Lee Y, Liu Y, Ho C, Huang C, Liu C, Ko W, Wang J, Tan H, Yu K, Chen Y, Chuang Y, Xu Y, Ni Y, Chen Y, Hsueh P. 2012. Epidemiology and antimicrobial susceptibility profiles of gramnegative bacteria causing urinary tract infections in the Asia-Pacific region: 2009-2010 results from the study for monitoring antimicrobial resistance trends (SMART). Intl J Antimicrobiol Agents 40S1: S37S43.

Munasik, Ambariyanto, Sabdono A, Wijayanti DP, Radjasa OK, Pribadi R. 2012. Sebaran spasial karang keras (Scleractinia) di Pulau Panjang, Jawa Tengah. Buletin Oseanografi Marina 1 (3): 16-24. [Indonesian]

National Institutes of Allergy and Infectious Diseases (NIAID). 2011 Antimicrobial (Drug) Resistance Causes http://www.niaid.nih.gov/topics/antimicrobialresistance/understandin g/pages/causes.aspx [8 Mei 2016]

Nikaido, H. 2009. Multidrug Resistance in Bacteria. Ann Rev Biochem 78: 119-146.

Radjasa OK, Wiese J, Sabdono A, Imhoff JF. 2008. Corals as source of bacteria with antimicrobial activity. J Coastal Dev 11 (3): 121-130.

Ramadhan NS, Rasyid R, Sy E. 2015. Daya hambat ekstrak daun pegagan (Centella asiatica) yang diambil di Batusangkar terhadap ertumbuhan kuman Vibrio cholerae secara in vitro. Jurnal Kesehatan Andalas 4 (1): 202-205. [Indonesian]

Rosenberg E, Gobhna U. 2011. Beneficial Microorganisms in Multicellular Life Forms. Springer-Verlag, Berlin. DOI: 10.1007/9783-642-21680-09.

Setiyono E, Heriyanto, Pringgenies D, Shioi Y, Kanesaki Y, Awai K, Brotosudarmo THP. 2019. Sulfur-containing carotenoids from a marine coral symbiont Erythrobacter flavus strain KJ5. Mar Drugs 17: 349. DOI: $10.3390 / \mathrm{md} 17060349$.

Silver LL. 2011. Challenges of antibacterial discovery. Clin Microbiol Rev 24 (1): 71-109. DOI: 10.1128/CMR.00030-10

Suharsono. 2008. Jenis-jenis karang di Indonesia. LIPI Press, Jakarta. [Indonesian]

Suwantarat N. Carroll KC. 2016. Epidemiology and molecular characterization of multidrug-resistant Gram-Negative bacteria in Southeast Asia. Antimicrob Resistant Infect Control 5: 15.

Sweet MJ, Croquer A. Bythell. 2010. Bacterial assemblages differ between compartments within the coral holobiont. Springer, Berlin. DOI: $10.1007 / \mathrm{s} 00338-010-0695-1$.

Veron JEN. 2000. CORALS of the World. Australian Institute of Marine Science, Townsville, Australia.

Wardhani LK. Sulistyani N. 2012. Uji aktivitas antibakteri ekstrak etil asetat daun binahong (Anredera scandens (L.) Moq.) terhadap Shigella flexneri beserta profil kromatografi lapis tipis. Jurnal Ilmiah Kefarmasian 2 (1): 1-16. [Indonesian]

Wegley L, Edwards R, Rodriguez-Brito B, Liu H, Rohwer F. 2007. Metagenomic analysis of the microbial community associated with the coral Porites astreoides. Environ Microbiol 9 (27): 7-19. DOI: 10.1111/j.1462-2920.2007.01383.x.

Yoghiapiscessa D. Batubara I. Wahyudi AT. 2016. Antimicrobial and antioxidant activities of bacterial extracts from marine bacteria associated with sponge Stylotella sp. Amer J Biochem Biotech 12 (1): $36-46$. 